for conservation globally

Threatened

通
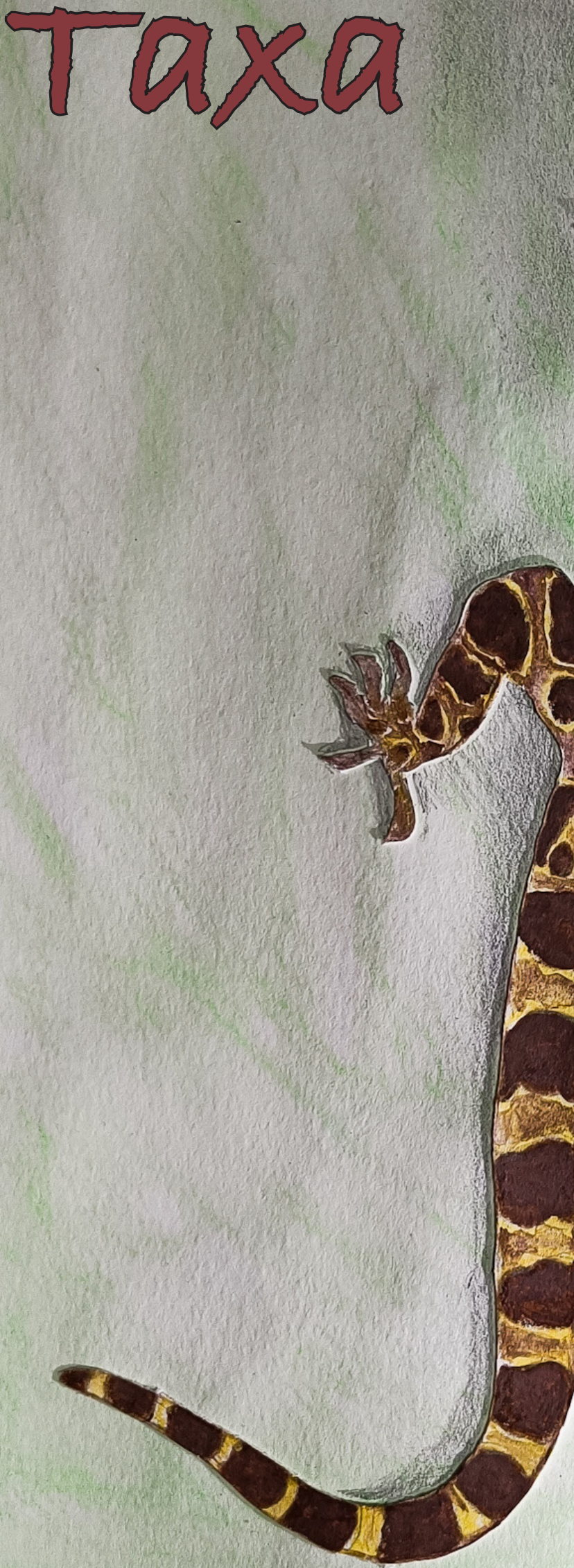

Open Access

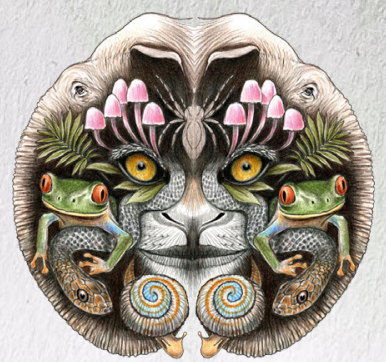

$10.1160 \mathrm{~g} / \mathrm{j}$ ott.2022.14.1.20311-20538 wWw.threatenedtaxa.org

26 January 2022 (Online \& Print) 14(1): 20311-20538 ISSN0974-7907 (Online) ISSN 0974-7893 (Print) 


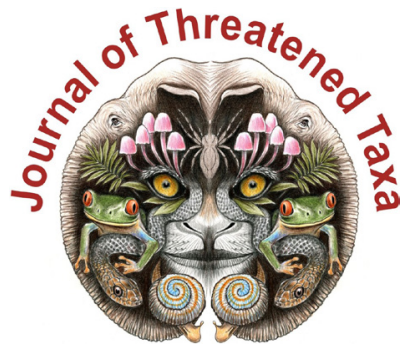

ISSN 0974-7907 (Online); ISSN $0974-7893$ (Print)

Publisher

Host

Wildlife Information Liaison Development Society

www.wild.zooreach.org

Zoo Outreach Organization www.zooreach.org

No. 12, Thiruvannamalai Nagar, Saravanampatti - Kalapatti Road, Saravanampatti, Coimbatore, Tamil Nadu 641035, India

Ph: +91 9385339863 | www.threatenedtaxa.org

Email: sanjay@threatenedtaxa.org

EDITORS

\section{Founder \& Chief Editor}

Dr. Sanjay Molur

Wildlife Information Liaison Development (WILD) Society \& Zoo Outreach Organization (ZOO),

12 Thiruvannamalai Nagar, Saravanampatti, Coimbatore, Tamil Nadu 641035, India

\section{Deputy Chief Editor}

Dr. Neelesh Dahanukar

Noida, Uttar Pradesh, India

\section{Managing Editor}

Mr. B. Ravichandran, WILD/ZOO, Coimbatore, India

\section{Associate Editors}

Dr. Mandar Paingankar, Government Science College Gadchiroli, Maharashtra 442605, India

Dr. Ulrike Streicher, Wildlife Veterinarian, Eugene, Oregon, USA

Ms. Priyanka Iyer, ZOO/WILD, Coimbatore, Tamil Nadu 641035, India

Dr. B.A. Daniel, ZOO/WILD, Coimbatore, Tamil Nadu 641035, India

\section{Editorial Board}

Dr. Russel Mittermeier

Executive Vice Chair, Conservation International, Arlington, Virginia 22202, USA

\section{Prof. Mewa Singh Ph.D., FASc, FNA, FNASc, FNAPsy}

Ramanna Fellow and Life-Long Distinguished Professor, Biopsychology Laboratory, and Institute of Excellence, University of Mysore, Mysuru, Karnataka 570006, India; Honorary Professor, Jawaharlal Nehru Centre for Advanced Scientific Research, Bangalore; and Adjunct Professor, National Institute of Advanced Studies, Bangalore

\section{Stephen D. Nash}

Scientific Illustrator, Conservation International, Dept. of Anatomical Sciences, Health Sciences Center, T-8, Room 045, Stony Brook University, Stony Brook, NY 11794-8081, USA

\section{Dr. Fred Pluthero}

Toronto, Canada

\section{Dr. Priya Davidar}

Sigur Nature Trust, Chadapatti, Mavinhalla PO, Nilgiris, Tamil Nadu 643223, India

\section{Dr. Martin Fisher}

Senior Associate Professor, Battcock Centre for Experimental Astrophysics, Cavendish

Laboratory, JJ Thomson Avenue, Cambridge CB3 OHE, UK

\section{Dr. John Fellowes}

Honorary Assistant Professor, The Kadoorie Institute, 8/F, T.T. Tsui Building, The University of Hong Kong, Pokfulam Road, Hong Kong

\section{Prof. Dr. Mirco Solé}

Universidade Estadual de Santa Cruz, Departamento de Ciências Biológicas, Vice-coordenado do Programa de Pós-Graduação em Zoologia, Rodovia Ilhéus/Itabuna, Km 16 (45662-000)

Salobrinho, Ilhéus - Bahia - Brasil

\section{Dr. Rajeev Raghavan}

Professor of Taxonomy, Kerala University of Fisheries \& Ocean Studies, Kochi, Kerala, India

\section{English Editors}

Mrs. Mira Bhojwani, Pune, India

Dr. Fred Pluthero, Toronto, Canad

Mr. P. Ilangovan, Chennai, India

Web Development

Mrs. Latha G. Ravikumar, ZOO/WILD, Coimbatore, India

\section{Typesetting}

Mr. Arul Jagadish, ZOO, Coimbatore, India

Mrs. Radhika, ZOO, Coimbatore, India

Mrs. Geetha, ZOO, Coimbatore India
Fundraising/Communications

Mrs. Payal B. Molur, Coimbatore, India

Subject Editors 2018-2020

Fungi

Dr. B. Shivaraju, Bengaluru, Karnataka, India

Dr. R.K. Verma, Tropical Forest Research Institute, Jabalpur, India

Dr. Vatsavaya S. Raju, Kakatiay University, Warangal, Andhra Pradesh, India

Dr. M. Krishnappa, Jnana Sahyadri, Kuvempu University, Shimoga, Karnataka, India

Dr. K.R. Sridhar, Mangalore University, Mangalagangotri, Mangalore, Karnataka, India

Dr. Gunjan Biswas, Vidyasagar University, Midnapore, West Bengal, India

\section{Plants}

Dr. G.P. Sinha, Botanical Survey of India, Allahabad, India

Dr. N.P. Balakrishnan, Ret. Joint Director, BSI, Coimbatore, India

Dr. Shonil Bhagwat, Open University and University of Oxford, UK

Prof. D.J. Bhat, Retd. Professor, Goa University, Goa, India

Dr. Ferdinando Boero, Università del Salento, Lecce, Italy

Dr. Dale R. Calder, Royal Ontaro Museum, Toronto, Ontario, Canada

Dr. Cleofas Cervancia, Univ. of Philippines Los Baños College Laguna, Philippines

Dr. F.B. Vincent Florens, University of Mauritius, Mauritius

Dr. Merlin Franco, Curtin University, Malaysia

Dr. V. Irudayaraj, St. Xavier's College, Palayamkottai, Tamil Nadu, India

Dr. B.S. Kholia, Botanical Survey of India, Gangtok, Sikkim, India

Dr. Pankaj Kumar, Kadoorie Farm and Botanic Garden Corporation, Hong Kong S.A.R., China

Dr. V. Sampath Kumar, Botanical Survey of India, Howrah, West Bengal, India

Dr. A.J. Solomon Raju, Andhra University, Visakhapatnam, India

Dr. Vijayasankar Raman, University of Mississippi, USA

Dr. B. Ravi Prasad Rao, Sri Krishnadevaraya University, Anantpur, India

Dr. K. Ravikumar, FRLHT, Bengaluru, Karnataka, India

Dr. Aparna Watve, Pune, Maharashtra, India

Dr. Qiang Liu, Xishuangbanna Tropical Botanical Garden, Yunnan, China

Dr. Noor Azhar Mohamed Shazili, Universiti Malaysia Terengganu, Kuala Terengganu, Malaysia

Dr. M.K. Vasudeva Rao, Shiv Ranjani Housing Society, Pune, Maharashtra, India

Prof. A.J. Solomon Raju, Andhra University, Visakhapatnam, India

Dr. Mandar Datar, Agharkar Research Institute, Pune, Maharashtra, India

Dr. M.K. Janarthanam, Goa University, Goa, India

Dr. K. Karthigeyan, Botanical Survey of India, India

Dr. Errol Vela, University of Montpellier, Montpellier, France

Dr. P. Lakshminarasimhan, Botanical Survey of India, Howrah, India

Dr. Larry R. Noblick, Montgomery Botanical Center, Miami, USA

Dr. K. Haridasan, Pallavur, Palakkad District, Kerala, India

Dr. Analinda Manila-Fajard, University of the Philippines Los Banos, Laguna, Philippines

Dr. P.A. Sinu, Central University of Kerala, Kasaragod, Kerala, India

Dr. Afroz Alam, Banasthali Vidyapith (accredited A grade by NAAC), Rajasthan, India

Dr. K.P. Rajesh, Zamorin's Guruvayurappan College, GA College PO, Kozhikode, Kerala, India

Dr. David E. Boufford, Harvard University Herbaria, Cambridge, MA 02138-2020, USA

Dr. Ritesh Kumar Choudhary, Agharkar Research Institute, Pune, Maharashtra, India

Dr. Navendu Page, Wildlife Institute of India, Chandrabani, Dehradun, Uttarakhand, India

\section{Invertebrates}

Dr. R.K. Avasthi, Rohtak University, Haryana, India

Dr. D.B. Bastawade, Maharashtra, India

Dr. Partha Pratim Bhattacharjee, Tripura University, Suryamaninagar, India

Dr. Kailash Chandra, Zoological Survey of India, Jabalpur, Madhya Pradesh, India

Dr. Ansie Dippenaar-Schoeman, University of Pretoria, Queenswood, South Africa

Dr. Rory Dow, National Museum of natural History Naturalis, The Netherlands

Dr. Brian Fisher, California Academy of Sciences, USA

Dr. Richard Gallon, llandudno, North Wales, LL30 1UP

Dr. Hemant V. Ghate, Modern College, Pune, India

Dr. M. Monwar Hossain, Jahangirnagar University, Dhaka, Bangladesh

Mr. Jatishwor Singh Irungbam, Biology Centre CAS, Branišovská, Czech Republic.

Dr. Ian J. Kitching, Natural History Museum, Cromwell Road, UK

Dr. George Mathew, Kerala Forest Research Institute, Peechi, India

For Focus, Scope, Aims, and Policies, visit https://threatenedtaxa.org/index.php/JoTT/aims_scope
For Article Submission Guidelines, visit https://threatenedtaxa.org/index.php/JoTT/about/submissions
For Policies against Scientific Misconduct, visit https://threatenedtaxa.org/index.php/JoTT/policies_various

continued on the back inside cover 


\title{
Population, distribution and diet composition of Smooth-coated Otter Lutrogale perspicillata Geoffroy, 1826 in Hosur and Dharmapuri Forest Divisions, India
}

\author{
Nagarajan Baskaran $^{1}$ (D), Raman Sivaraj Sundarraj ${ }^{2}$ (D) \& Raveendranathanpillai Sanil ${ }^{3}$ (D) \\ ${ }^{1}$ Asian Nature Conservation Foundation, Centre for Ecological Sciences, Indian Institute of Science, Bengaluru, Karnataka 560012, India. \\ ${ }^{1}$ Present Address: Department of Zoology \& Wildlife Biology, A.V.C. College (Autonomous), Mannampandal, Mayiladuthurai, \\ Tamil Nadu 609305, India. \\ 2,3 Department of Zoology \& Wildlife Biology, Government Arts College, Udhagamandalam, Tamil Nadu 643002, India. \\ ${ }^{1}$ nagarajan.baskaran@gmail.com (corresponding author), ${ }^{2}$ ottersundar@gmail.com, ${ }^{3}$ sanilravi@gmail.com
}

\begin{abstract}
Living in different aquatic ecosystems, otters play a vital role in maintaining aquatic species assemblages, particularly fish communities. Thus their wellbeing indicates the health of wetland ecosystems. Smooth-coated Otter Lutrogale perspicillata, a piscivorous mustelid, is widely distributed across Asia. Its population is declining due to habitat transformation, pollution and hunting. This study aimed to understand the ecological requirements of the species by assessing its distribution and its determinants, population and diet composition along the Cauvery River in Hosur and Dharmapuri Forest Divisions. Through monthly extensive surveys between December 2010 and February 2011, covering $62.5 \mathrm{~km}$ of Cauvery from the Karnataka border to Palar River junction, this study identified and mapped a $31 \mathrm{~km}$ stretch from Dubguli (Yellolapatti) to Biligundlu (Musulumaduvu) as an otter distribution area. Comparison of ecological parameters including bank type, water depth, river width, human disturbance, vegetation cover and water current with the distribution pattern of otters across 125 blocks revealed that water depth and vegetation cover influenced otter distribution positively, while human disturbance had negative influence (these three variables explained $54 \%$ of variation in otter distribution). Based on direct sightings, seven different groups consisting of 36 individuals were estimated as the minimum population. The mean group size was $3.8 \pm 0.16$ (range: $2-7$ ) individuals. Twenty-one otter spraints were analyzed to determine diet composition, revealing that otters feed on insects, molluscs, crabs, fish, frogs, reptiles and birds. Fish constituted the bulk of otter diets. Conservation measures like reducing anthropogenic pressures (e.g., fishing, cattle pens, tourism), increasing awareness of sustainable fishing to stakeholders, and instituting long-term monitoring programs are suggested for the longterm conservation of otters in the study area.
\end{abstract}

Keywords: Carnivora, Cauvery River, determinants, diet, group size, Hosur and Dharmapuri Forest Divisions, Mustelidae, population, water depth influence.

Citation: Baskaran, N., R.S. Sundarraj \& R. Sanil (2022). Population, distribution and diet composition of Smooth-coated Otter Lutrogale perspicillata Geoffroy, 1826 in Hosur and Dharmapuri Forest Divisions, India. Journal of Threatened Taxa 14(1): 20469-20477. https://doi.org/10.11609/jott.7477.14.1.20469-20477

Copyright: (c) Baskaran et al. 2022. Creative Commons Attribution 4.0 International License. JoTT allows unrestricted use, reproduction, and distribution of this article in any medium by providing adequate credit to the author(s) and the source of publication.

Funding: Asian Nature Conservation Foundation, C/o. Centre for Ecological Sciences, Indian Institute of Science, Bangalore and Kenneth Anderson Nature Society, Hosur, Tamil Nadu.

Competing interests: The authors declare no competing interests.

Author details: NagARAJAn BASKARAN, Assistant Professor, teaching MSc Wildlife Biology and BSc Zoology at the Dept. of Zoology \& Wildlife Biology, A.V.C. College (Autonomous). Research interest-mammalian behavioural ecology. Studying Asian Elephants since 1990 in the Eastern, and Western Ghats and Eastern Himalayas. Member of IUCN-SSC Asian Elephant Specialist Group since 2002. Raman Sivaraj Sundarraj-a guest lecturer at the Dept. of Zoology \& Wildlife Biology, Govt. Arts College, Udhagamandalam. Teaching BSc \& MSc Wildlife Biology. Research Interest-entomology. Raveendranathanpillai Sanil-Associate Professor at the Dept. of Zoology \& Wildlife Biology, Govt. Arts College, Udhagamandalam. Teaching BSc \& MSc Zoology. Research Interest-molecular biology \& bio-chemistry.

Author contributions: NB-conceiving the concept, planning \& execution, data analysis \& writing. RSS - data collection, entry \& preliminary analysis. RS-helping in data analysis \& writing.

Acknowledgements: We are grateful to the Tamil Nadu Forest Department for permitting this study and the Asian Nature Conservation Foundation (ANCF) for funding. We also thank Mr. K.G. Avinash, GIS Expert, ANCF in helping us to produce the distribution maps.
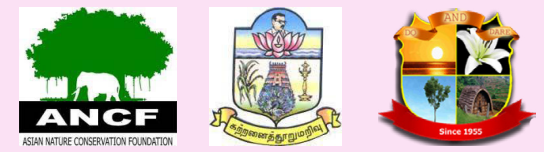


\section{INTRODUCTION}

Otters are piscivorous mustelids belonging to the family Mustelidae and subfamily Lutrinae. Of the five species of otters found in Asia, three occur in India: the Smooth-coated Otter Lutrogale perspicillata (Image 1), the Eurasian Otter Lutra lutra, and the Oriental Smallclawed Otter Aonyx cinerea (Hussain 1993; Prater 1998; Reuther 1999; Menon 2003; Raha \& Hussain 2016). The Smooth-coated Otter is distributed widely throughout India south of the Himalaya (Pocock 1949; Prater 1971; Hussain 1993) and also in Myanmar, Indonesia, Kampuchea, Laos, Malaysia, Vietnam, southwestern China, and Brunei, with an isolated subspecies, $L$. perspicillata maxwelli, found in the marshes of southern Iraq (Mason \& Macdonald 1986).

Living in different aquatic ecosystems (Pardini 1998), otters play a major role in maintaining aquatic species communities, particularly fish communities (Sivasothi 1995; Anoop \& Hussain 2005). They are health indicators of wetland ecosystems, being sensitive to degradation of habitat and the food chain (Erlinge 1972). Loss of wetlands habitat, reduction in prey species, disturbances from developmental projects and poaching are the major threats to otter survival in India (Nagulu et al. 1999a,b; Meena 2002). The Smooth-coated Otter is presently listed as a 'Vulnerable' species on the IUCN Red List (de Silva et al. 2015), Appendix I in CITES (CoP 2019) and is protected under Schedule II in Indian Wildlife (Protection) Act (1972). Despite their wide distribution and vital role in the wetland ecosystem, not much attention has been paid to understand their ecology. The existing populations of the species and their habitat have never been systematically surveyed throughout India (Hussain \& Choudhury 1997). Systematic data on their habitat, distribution, population, and feeding ecology are essential for conservation planning and management of the species in India.

In southern India, the species has been studied in Periyar Tiger Reserve, Kerala (Anoop 2001; Anoop \& Hussain 2005) and in the Cauvery River in Karnataka (Shenoy 2005; Shenoy et al. 2006), in particular the Cauvery Wildlife Sanctuary. This study aimed to cover the entire range of the species in Cauvery River to evaluate the current distribution, population, group size, and diet.

\section{Study Area}

The study was carried out along the Cauvery River within Hosur and Dharmapuri Forest Divisions, stretching from Ichiebara (12.198 N, 77.593 E) to the junction of

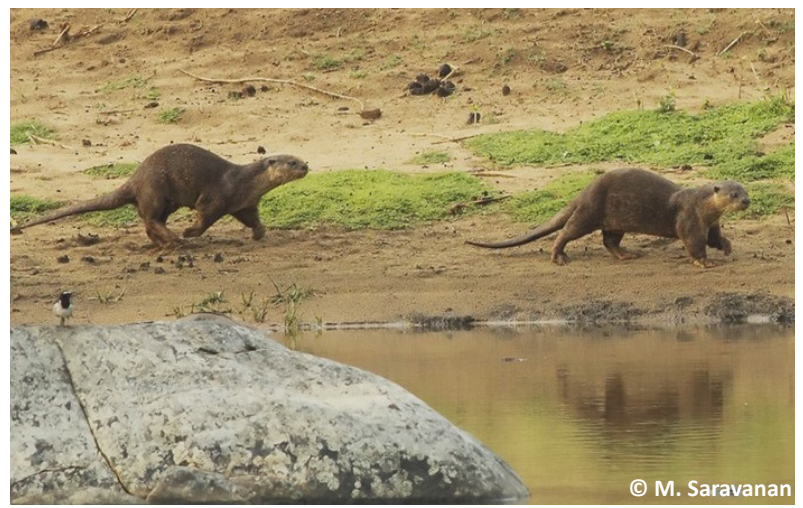

Image 1. Smooth Coated Otter Lutrogale perspicillata

Palar (11.953 N, 77.676 E), a tributary of the Cauvery (Image 2) between December 2010 and August 2011. The river stretches over $62 \mathrm{~km}$ and varies in altitude from $307 \mathrm{~m}$ upstream to $236 \mathrm{~m}$ downstream. Cauvery is a major perennial river, the eighth largest river of the subcontinent and ranks as a medium river on the global scale (Jayaram 2000). It provides water to most areas in Karnataka and Tamil Nadu states. The Cauvery originates at Talakaveri (12.198 N, 77.593 E) in Kodagu district of Karnataka in the Western Ghats at an altitude of 1,341 $\mathrm{m}$. From the edge of the Western Ghats, within sight of the Arabian Sea, to the Bay of Bengal, the river traverses through nearly $770 \mathrm{~km}$ in a roughly north-west to southeast direction. It passes through the Western Ghats, the Deccan Plateau and the Eastern Ghats, crossing diverse habitats ranging from high altitude shola forests to the dry scrub jungles of the plains (Jayaram 2000). It has 29 major tributaries and its basin receives rainfall from the south-west and north-east monsoons with a major share from south-west monsoon. The river basin in the study area provides natural habitat to a diverse highly threatened mammalian species. The riparian habitat offers an important habitat to the Smooth-coated Otter (Baskaran et al. 2010). The river basin and its adjoining areas in Hosur-Dharmapuri Forest Divisions are subject to severe anthropogenic pressure in terms of cattle grazing, MFP collection, fishing, tourism, and pilgrimage.

\section{MATERIALS AND METHODS}

\section{Mapping of otter habitats}

To map the distribution of otter and its habitats, the $62.5 \mathrm{~km}$ of the Cauvery River falling within the study area was marked into 125 survey blocks of $500 \mathrm{~m}$ and surveyed by foot on a monthly basis from 


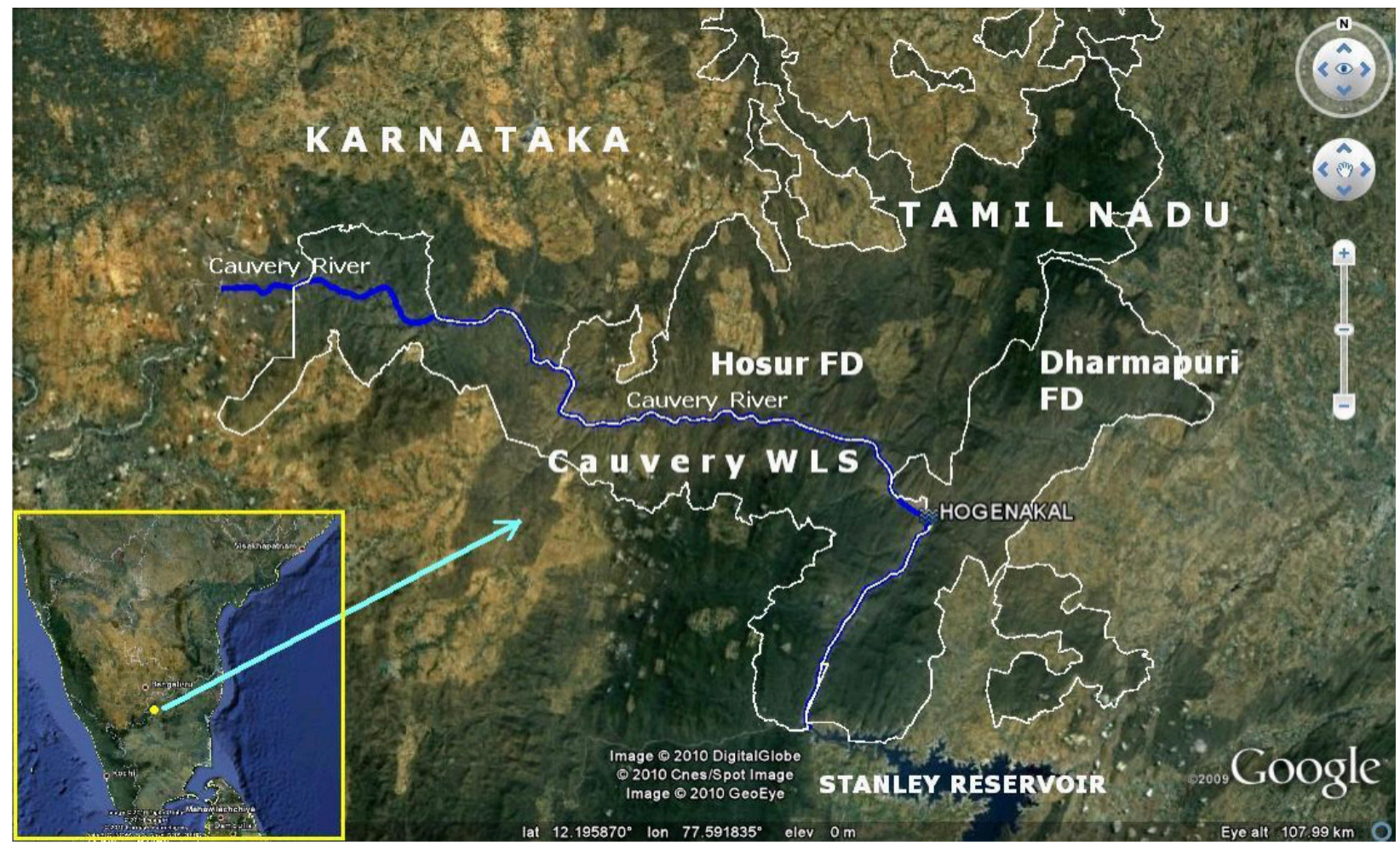

Image 2. Map showing the study area Cauvery River along Hosur-Dharmapuri Forest Divisions in Tamil Nadu with adjoining forest division the Cauvery Wildlife Sanctuary in Karnataka.

December 2010 to February 2011. During each survey, the presence or absence of otters based on direct sightings and indirect evidence was recorded in each block. All approachable islands within the river were also surveyed. The indirect evidences considered for their presence include spraints (fecal matter), tracks, holts, food remains, and scrapes (Ottino \& Giller 2004). Spraints were categorized according to consistency and degree of bleaching, they were considered fresh when found with moisture and strong odour, old when intact but without moisture and odour, and very old if disintegrated without moisture and odour. The tracks, holts and food remains were divided into three different categories based on moisture, appearance (disturbed/ undisturbed), condition in case of food remains (fresh/ old/very old) and when found with spraints their status was taken into account for categorization. At every sighting of otters and their evidence, the geographical location (latitude and longitude) and the survey block number were noted down using a global positioning system (GPS). Superimposing the otter location geocoordinate into Google Earth map, we established the otter distribution map.

\section{Assessment of factors influencing distribution}

Studies on otters (Hussain \& Chodhury 1997; Ottino \& Giller 2004; Anoop \& Hussain 2005; Shenoy et al. 2006) show that variables such as river bank type (earthen, sandy, and rocky) river width, water depth, water current (low and high), vegetation density and human disturbance influence the distribution pattern of otters. The human disturbance was rated as low for areas with infrequent disturbance by local people due to fuel wood and MFP collection, bathing and cattle grazing, medium for areas with frequent disturbance by local people due to fuel wood, MFP collection, self-fishing, fire for cooking, bathing, cattle grazing and eco-tourism, and high for areas with regular disturbance by local people due to fuel wood collection, self/commercial fishing, MFP collection, bathing, cattle grazing and cattle pen, tourism including seasonal pilgrimage, fire for cooking, and discarded food. These variables were evaluated at each 500-m interval in the survey blocks. At each survey block, the river width, water depth and water current were evaluated at three to five locations and averaged for each block. Within each survey block, vegetation density was assessed at 100-m intervals, placing a 20 $\mathrm{m}^{2}$ quadrat for trees, $5 \mathrm{~m}^{2}$ quadrat shrubs, and $1 \mathrm{~m}^{2}$ quadrat for grass species and averaged for each block. 
The difference in otter abundance observed among (like river bank type: earthen, sandy, rocky) and between categories in different variables (like water current: low and high) were tested for statistical significance, respectively, employing, Kruskal-Wallis $\mathrm{H}$ test and MannWhitney U-test in SPSS Version 16.0.

The influence of ecological factors on the distribution of otters was explored using multiple regression analysis after testing for normality. In the multiple regression framework, the dependent variable was the otter abundance, arrived based on both direct sighting of otter and their indirect evidences, while the independent variables were the river bank type (earthen, sandy, and rocky), river width, water depth, water current, vegetation density and human disturbance. At first the relationship between the dependent variable and independent variables were tested using scatter plots. Based on the relationship of independent variables, the variable was entered either in linear form or non-linear form with quadratic term. When the relationship was quadratic, both independent variable and its square term were entered into the multiple regression models. If the quadratic term turned out to be insignificant, it was dropped. At the end, only significant independent variables were retained in the equation.

\section{Evaluation of population and group size}

Although the presence or absence of otters could be assessed through direct sighting of otters and their evidence, no simple foolproof method is available for censusing river otters (Melquist \& Dronkert 1987). A number of factors influence marking intensity and hence this measure cannot be used as a direct indicator of population size (Jefferies 1966; Krqsuuk \& Conroy 1987). The Smooth-coated Otter lives in social groups that vary in size and change with seasons (Hussain 1996; Anoop \& Hussain 2005). The population size was estimated based on the spatial distribution of various groups, differentiated based on group size and their movement pattern observed during the study period. In total, seven different groups were differentiated based on group size and movement pattern and the total number of individuals recorded within each group was taken into account to estimate the population size in the study area. Data on group size were recorded on each sighting of the identified groups. Mean group size was estimated for the seven groups we identified by averaging the groups size recorded in the multiple sightings of the respective groups. Similarly, the mean group size for overall population was arrived averaging the group size of all the seven groups.

\section{DIET COMPOSITION}

Spraint collection: To study the diet composition of Smooth-coater Otters, spraint analysis was used following Anoop \& Hussain (2005), as direct observation was not possible due to anthropogenic disturbance. Spraints of the otter were collected visiting the riparian habitat on fortnight interval. Spraints were collected in self-lock polythene covers and labeled with different variables such as status of the spraint, microhabitat, date, and location. The collected samples were airdried at room temperature and stored separately for laboratory analysis.

Reference sample of fish collection: To identify the fish species from the spraint, a checklist of fish presents in the Cauvery River was prepared. Different fish species were caught from each survey block-using a gas net. The fish species were identified using standard reference books (Jayaram 1994) with the help of experts from the Indian Institute of Science, Bengaluru. From each species, a set of scales were collected and permanent reference slides prepared by mounting with a drop of glycerin and seal with adhesive.

Spraint analysis: The air-dried spraints were weighed to nearest $0.01 \mathrm{~g}$ using a physical balance. From each spraint, mucus was removed soaking it in a solution of oxidizing agent (Webb 1976). The spraint was washed with a sieve of $0.5 \mathrm{~mm}$ mesh and dried again. All prey remains were segregated under a binocular microscope, assigned to food categories and weighed. Species level identification of the fish were done using reference slides. Other species like insects, mussels, crabs, amphibians, reptiles, and birds were broadly segregated into order level using feathers, teeth and other bones, insect remains, shells, etc. The buff white colour of the bone was used to identify the frogs eaten by otters, while in the case of crab and mussel, general shape, colour and shape exoskeleton were used as key (Anoop \& Hussain 2005). The segregated food categories were air-dried and weighed using a physical balance.

Data are presented for each food category using three different methods: (i) Percent frequency $\mathrm{F}=$ number of spraints containing a given prey category divided by total number of spraints $\times 100$ (Jenkins et al. 1979), (ii) Relative percentage frequency $R=$ number of occurrences of a food category divided by total number of occurrences of all prey categories $\times 100$ (Rowe-Rowe 1977), and (iii) Dry weight Dw= dry weight of a given food category divided by total dry weight of all prey categories $\times 100$. 


\section{RESULTS}

\section{Distribution}

58 direct sightings and 31 indirect indications were recorded across 125 survey blocks in the Cauvery River. Direct sightings and indirect evidence showed that otter distribution was restricted to the stretch from Dubguli (Yellolapatti) to Biligundlu (Musulumaduvu) downstream (Image 3). The total length of this stretch is $31 \mathrm{~km}$ within this study area, no sighting or evidence of otters was found between Anchetty stream to Uganium (around $6 \mathrm{~km}$ ). Further, there was no direct sighting or indirect evidence of otters in the rest of $31.5 \mathrm{~km}$ from Musulumaduvu to Palar indicating restricted distribution of otter in the Hosur and Dharmapuri Forest Divisions.

\section{Factors influencing distribution}

Otter were observed to be significantly concentrated in river stretches with higher water depth $\left(\mathrm{K}-\mathrm{W} \chi^{2}=\right.$ 11.358, $d f=2, P<0.01)$, in islands with shrub/grass cover (K-W $\left.\chi^{2}=40.595, d f=2, P<0.001\right)$, and in areas with lower water current $(\mathrm{M}-\mathrm{W} \mathrm{U}=1098, P<0.05)$ and human disturbance (K-W $\chi^{2}-33.379, d f=2, P<0.001$ ) (Table 1). Further comparison of otter abundance recorded in the five blocks with the ecological factors prevailed in the respective block revealed that water depth (Coefficient \pm SE $=0.133 \pm 0.034, P<0.001$ ) and vegetation cover (Coefficient $\pm \mathrm{SE}=0.031 \pm 0.005, P$ $<0.001$ ) influenced the otter abundance positively, while the human disturbance influenced negatively (Coefficient \pm SE $=-0.664 \pm 0.190, P<0.01$ ) and these three variables explained $54 \%$ otter of the variations in distribution (Table 2).

\section{Population and group size}

The study, based on the group size and spatial locations recorded from the 47 direct sightings, differentiated seven different groups of otters. From these seven groups, the study recorded a minimum of 36 individuals during the survey (Table 3). Out of 47 direct sightings of otters, the study estimated the mean group size of $3.8 \pm 0.16$. The minimum and maximum group size recorded was two and seven individuals, respectively.

\section{Diet composition}

The analysis of 21 otter spraints revealed that otters feed on prey items which include insects, molluscs, crabs, fish, frogs, reptiles, and birds. Fish appeared most frequently in the diet of otters (Table 4). The fish species Labeo callbasu occurred in 15 out of 21 scats, and also contributed $90 \%$ of dry weight of all the food

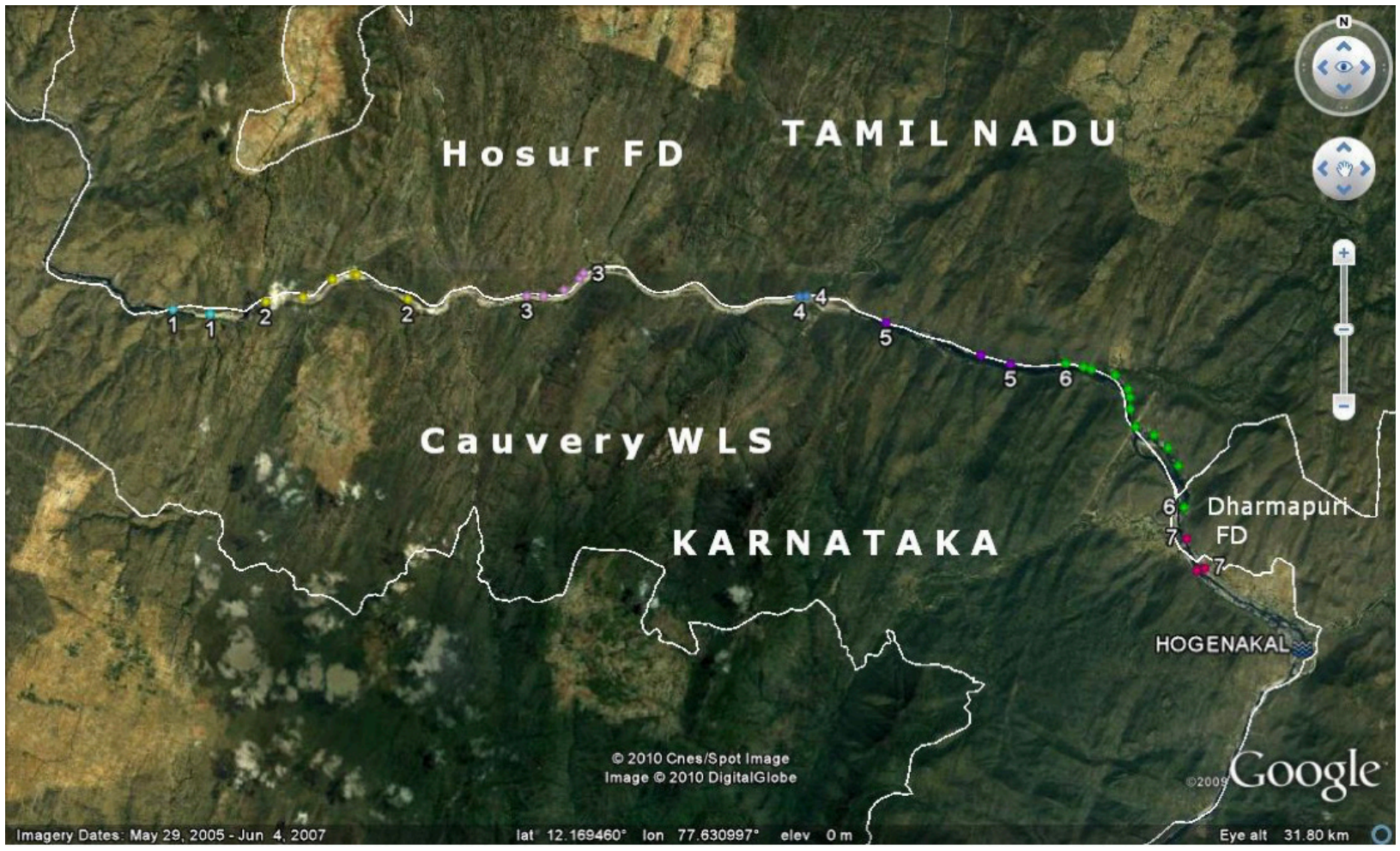

Image 3. Map of study area showing seven otter groups' distribution area along Cauvery River. 
Table 1. Distribution pattern of smooth-coated otter in relation to ecological factors along Cauvery River in Hosur and Dharmapuri Forest Divisions, Eastern Ghats.

\begin{tabular}{|c|c|c|c|c|c|}
\hline Factor & $\begin{array}{l}\text { Category } \\
\text { (n) }\end{array}$ & $\begin{array}{l}\text { Otter abundance } \\
\text { mean } \pm \text { se }\end{array}$ & $\begin{array}{l}\text { Kruskal-Wallis }\left(\chi^{2}\right) \text { / } \\
\text { "Mann-Whitney U }\end{array}$ & $d f$ & $P$ \\
\hline \multirow{3}{*}{ Bank type } & Earthen (37) & $0.41 \pm 0.180$ & \multirow{3}{*}{1.36} & \multirow{3}{*}{2} & \multirow{3}{*}{0.507} \\
\hline & Sandy (45) & $0.84 \pm 0.270$ & & & \\
\hline & Stony (43) & $0.51 \pm 0.271$ & & & \\
\hline \multirow{3}{*}{ Water depth } & Low (26) & $0.12 \pm 0.085$ & \multirow{3}{*}{11.358} & \multirow{3}{*}{2} & \multirow{3}{*}{0.003} \\
\hline & Medium (58) & $0.40 \pm 0.165$ & & & \\
\hline & High (41) & $1.20 \pm 0.355$ & & & \\
\hline \multirow{3}{*}{ River width } & Low (30) & $0.93 \pm 0.437$ & \multirow{3}{*}{0.715} & \multirow{3}{*}{2} & \multirow{3}{*}{0.699} \\
\hline & Medium (65) & $0.58 \pm 0.178$ & & & \\
\hline & High (30) & $0.30 \pm 0.153$ & & & \\
\hline \multirow{3}{*}{ Vegetation } & Low (17) & 0.0 & \multirow{3}{*}{40.595} & \multirow{3}{*}{2} & \multirow{3}{*}{0.000} \\
\hline & Medium (59) & 0.0 & & & \\
\hline & High (49) & $1.53 \pm 0.329$ & & & \\
\hline \multirow{2}{*}{ Water current } & Low (29) & $1.10 \pm 0.410$ & \multirow{2}{*}{ "10.98 } & & \multirow{2}{*}{0.01} \\
\hline & High (96) & $0.45 \pm 0140$ & & & \\
\hline \multirow{3}{*}{ Human disturbance } & Low (28) & $2.32 \pm 0.520$ & \multirow{3}{*}{33.379} & \multirow{3}{*}{2} & \multirow{3}{*}{0.000} \\
\hline & Medium (57) & $0.18 \pm 0.062$ & & & \\
\hline & High (40) & 0.0 & & & \\
\hline
\end{tabular}

Table 2. Regression equation model to explore the influence of ecological factors on the distribution pattern of Smooth-coated Otter along Cauvery River in Hosur and Dharmapuri Forest Divisions, Eastern Ghats.

\begin{tabular}{|l|c|c|c|c|c|}
\hline Variable & Coefficient \pm Std. error & $\boldsymbol{P}$ & model $\left(\mathbf{R}^{2}\right)$ & $\boldsymbol{F}$ & model $(\boldsymbol{p})$ \\
\hline Constant & $0.348 \pm 0.523$ & 0.507 & & \\
\cline { 1 - 3 } Water depth & $0.133 \pm 0.034$ & 0.000 & \multirow{2}{*}{0.545} & 33.616 & 0.000 \\
\cline { 1 - 3 } Human disturbance & $-0.664 \pm 0.190$ & 0.001 & & \\
\cline { 1 - 3 } Vegetation cover & $0.031 \pm 0.005$ & 0.000 & & & \\
\hline
\end{tabular}

items, indicating importance of Labeo in the otter diet in the study area. It is interesting to note that higher vertebrates such as reptiles and birds seldom feature in the otter diet. In terms of dry weight, fish accounted for $90 \%$ of otter diets (Table 4 ), followed by birds (5\%), frogs $(2 \%)$, molluscs $(1 \%)$, and crabs (1\%). Prey items such as insect and reptiles formed less than one percent of the overall diet of otters.

\section{DISCUSSION}

\section{Distribution of otter}

This study identified $31 \mathrm{~km}$ of otter habitat in the study area. The distribution of otter habitat was mapped during the dry season, and it is likely that during the wet season otters may expand their distribution area. Also, absence of otter signs in a particular place does not necessarily mean otters are absent from the area, as occasionally they may inhabit an area without depositing spraints (Jenkins \& Burrows 1980; Melquist \& Hornocker 1983; Kruuk et al. 1987), although this is infrequent (Chehebar 1985). Nevertheless, the findings on the otter distribution area, mapped by the present study, based on dry season observations, have vital management implications, as it is a pinch period in which animals restrict themselves to smaller areas due to resource limitations, which need to be protected from human disturbance for the long-term conservation of the species.

\section{Factors influencing distribution}

The multiple regression analysis revealed among the five ecological correlates tested, water depth, vegetation 
Table 3. Population size and group size of Smooth-coated Otter estimated based on seven different groups occupying the study area during December 2009-March 2010.

\begin{tabular}{|c|c|c|c|}
\hline Group ID & $\begin{array}{c}\text { Survey blocks } \\
\text { used }\end{array}$ & $\begin{array}{c}\text { Total number of } \\
\text { individuals }\end{array}$ & $\begin{array}{c}\text { Group size mean } \\
\pm \text { SE }\end{array}$ \\
\hline 1 & 12 to 15 & 5 & $4.0 \pm 0.45$ \\
\hline 2 & 18 to 25 & 4 & $3.3 \pm 0.18$ \\
\hline 3 & 33 to 37 & 5 & $4.2 \pm 0.37$ \\
\hline 4 & 45 to 49 & 5 & $3.7 \pm 0.67$ \\
\hline 5 & 52 to 57 & 7 & $5.5 \pm 0.96$ \\
\hline 6 & 62 to 68 & 5 & $3.5 \pm 0.21$ \\
\hline 7 & 71 to 74 & 5 & $3.7 \pm 0.33$ \\
\hline Total & 12 to 74 & 36 & $3.8 \pm 0.16$ \\
\hline
\end{tabular}

cover influenced otter distribution positively, on the other hand, human disturbance influenced negatively. The positive influence of vegetation cover in the form of dense shrub/grass cover along river banks and islands on otter distribution is likely due to the preference of such areas by otters for excavating their holts, most of which were recorded in river stretches associated with dense undergrowth. This has also been reported in earlier findings (Shenoy 2002, 2005; Annob \& Hussain 2005; Shenoy et al. 2006). Similarly, water depth also showed a positive influence on otter distribution. Since the study period (December 2009-February 2010) was largely confined to the dry season, it is likely that during that season otters in the study area preferred stretches with deep water to avoid high temperatures. Also, Paterson \& Whitfield (2000) reported that fish distribution is closely correlated to water depth. It is important to note the decrease in otter abundance with human disturbance through fishing, bathing, cattle grazing, and forest product collection, which could affect the otter distribution adversely. Direct observations of otters suggest bank edges with sandy soil and islands of rocky outcrops and boulders provide ideal microhabitats for feeding (Burton 1968; Channin 1985), sleeping (Channin 1985; Nolet et al. 1993), grooming (Nolet et al. 1993), playing (Shariff 1984), and territory marking (Green et al. 1984; Kruuk 1992). Islands and rocky outcrops in the middle of the river are safer for aquatic species like otter to escape from threats as compared to river banks, where anthropogenic disturbances are more and such islands are ideal if they contain vegetation undergrowth to provide cover (Shenoy 2002). Prey availability is probably a crucial factor influencing the distribution of the otters follow their food abundance gradient and alter their home ranges accordingly (Mason \& Macdonald 1986). Our attempt to estimate the prey abundance
Table 4. Frequency of occurrence of various prey items identified from Smooth-coated Otter spraints in the study area December 2009-March 2010.

\begin{tabular}{|c|c|c|c|}
\hline \multirow[b]{2}{*}{ Prey items } & \multicolumn{2}{|c|}{ Occurrence } & \multirow[b]{2}{*}{$\begin{array}{c}\text { Dry weigh } \\
\text { (\%) }\end{array}$} \\
\hline & $\begin{array}{c}\text { Percent } \\
\text { frequency }\end{array}$ & $\begin{array}{c}\text { Relative } \\
\text { percent } \\
\text { frequency }\end{array}$ & \\
\hline Insects & 9.5 & 4.5 & 0.10 \\
\hline Molluscs & 9.5 & 4.5 & 1.12 \\
\hline Crab & 4.8 & 2.3 & 1.40 \\
\hline \multicolumn{4}{|l|}{ Pisces } \\
\hline Labeo callbasu & 71.4 & 34.1 & \multirow{5}{*}{89.80} \\
\hline Channa argus & 9.5 & 4.5 & \\
\hline Masatcembalus sp. & 14.3 & 6.8 & \\
\hline Tor khudree & 9.5 & 4.5 & \\
\hline Notopterus notopterus & 4.8 & 2.3 & \\
\hline Unidentified fish & 33.3 & 15.9 & \\
\hline Frog & 28.6 & 13.6 & 2.20 \\
\hline Reptile & 9.5 & 4.5 & 0.40 \\
\hline Birds & 4.8 & 2.3 & 4.70 \\
\hline
\end{tabular}

did not yield adequate data due to the reason that much of the river stretches in the study area are with low water depth, which could not be sampled using gill net. However, fish being the major prey of the Smoothcoated Otters, fish must be available all the year round, if otters are to remain as permanent residents in an area (Melquist \& Hornocker 1983). Although, water depth, ground vegetation and human disturbance explained $54 \%$ of the otter distribution in the study area, the rest $46 \%$ could be a function of fish abundance, which is not addressed adequately in this study.

\section{Population and group size}

Although no data is available from southern region for comparison, a detailed survey on population conducted along a 425-km stretch of the Chambal River in a sanctuary reports 29 otters during 1988 and 14 in 1992 (Hussain \& Choudhury 1997). The present report of 36 otters for the entire stretch of $62 \mathrm{~km}$ surveyed (from Ichiebara on the upstream of Cauvery River to the junction of Palar in the downstream) represents a healthy population. Since the study covered the Cauvery River stretch in the upstream only from Tamil Nadu boundary, it is likely the same river further up in Karnataka region could also be supporting Smoothcoated Otters and thus actual population may be larger than reported here. Overall, the study estimates a mean group size of 3.9 individuals based on 47 sightings. The mean group size was marginally higher during February 
(4.3 individuals) compared to January (3.4 individuals). In National Chambal Sanctuary, India, Hussain (1996) estimated a mean group size of 4.6 individuals based on larger sample size $(n=422)$. The present finding of 3.9 individuals per group is comparable to those from Hussain (1996). The smaller group size in the present study could be attributed to the short-term nature representing only the dry season and the absence of wet season data in which the group size reported to be larger (Hussain 1993).

\section{Diet composition}

Fish constituted the major prey items during the study, both in terms of frequency of occurrence and dry weight. When occurrence of a food item is high, that food is important for the dependent species (Knudsen \& Hale 1968). Similar to the present study, fish were identified as the stable food of Smooth-coated Otters elsewhere in southern India (Balasubramanian 1989; Anoop \& Hussain 2005). Although the otters are mainly piscivorous animals, in the present study area they also feed on a variety of other prey items like insects, molluscans, crabs, reptiles, frogs, and birds as reported elsewhere (Anoop \& Hussain 2005). Similar to the present study, Norris (1974) found the occurrence of freshwater mussels as part of the otter diet. Otters rarely preyed on birds, although reported elsewhere from other parts of India (Anoop \& Hussain 2005). A similar trend in diet composition has been reported for the Eurasian Otter Lutra lutra L. (Ottino \& Giller 2004).

\section{CONCLUSIONS AND RECOMMENDATIONS}

The study shows that Smooth-coated Otters are distributed along the Cauvery River from Dubguli (Yellolapatti) upstream, to Biligundlu (Musulumaduvu) downstream. While water depth and vegetation cover influenced the otter distribution positively, human disturbance influenced it negatively. The study estimated 36 individuals as the minimum population of otter in the area and showed that otters feed on insects, molluscs, crabs, fishes, frogs, reptiles, and birds with fish as the principal component. As the survival of otters depend on the fish population in the area, protection of fish fauna of Cauvery River and the riverine system are essential for the long-term conservation of the otters. Unfortunately, there is tremendous pressure on fish fauna in the study area from local people due to commercial fishing, which needs to be reduced to a sustainable level as the first step for conservation of otters. Apart from fishing, the riparian habitats also experience other kinds of anthropogenic pressure, including over grazing by scrub cattle, cattle-pen and non-timber forest produce collections and disturbances. Pollution from seasonal pilgrimage and regular tourism as reported in Baskaran et al. (2010), which should be regulated/ stopped for the conservation of riparian habitats of the Cauvery River and its dependent species like smooth-coated otters. Increased awareness of sustainable fishing by the community and long-term monitoring will also benefit the otters' survival.

\section{REFERENCES}

Anoop, K.R. \& S.A. Hussain (2005). Food and feeding habits of smoothcoated otters (Lutra perspicillata) and their significance to the fish population of Kerala, India. Journal of Zoology (London). 266: 15-23. https://doi.org/10.1017/S0952836905006540

Anoop, K.R. (2001). Factors affecting habitat selection and feeding habits of Smooth-coated Otter (Lutra perspicillata) in Periyar Tiger Reserve, Kerala. M.Sc. Thesis. Wildlife Institute of India, Dehra Dun, India, $62 \mathrm{pp}$.

Balasubramanian, M. (1989). Food habits of Smooth-coated Otters Lutra perspicillata in Mudumalai Wildlife Sanctuary, Tamil Nadu. Unpublished M.Sc. Dissertation. A.V.C. College, Mannampandal, Mayiladuthurai, Tamil Nadu, 20 pp.

Baskaran, N., G. Nayak, M. Saravanan, K. Senthilkumar, S.R. Chandramouli \& K.G. Avinash (2010). Vertebrate faunal diversity in Hosur Forest Division and its contiguous habitats in Dharmapuri Forest Division of Tamil Nadu. Summary Report Tamil Nadu Forest Department, May 2010, 31 pp.

Burton, M. (1968). Wild Animals of the British Isles, pp. 131-136. In: The Otter. Warne, F. and Co Ltd, London.

Channin, P. (1985). The Natural History of Otters. Christopher Helm, London, $179 \mathrm{pp}$.

Chehebar, C. (1985). A survey of the Southern River Otter Lutra provocax Thomas in Nahuel Huapi National Park, Argentina. Biological Conservation 32: 299-307. https://doi.org/10.1016/00063207(86)90056-X

CITES (2019). CITES $18^{\text {th }}$ Conference of Parties (CoP) held in Geneva on 26 August 2019.

de Silva, P., W.A. Khan, B. Kanchanasaka, L.I. Reza, M.M. Feeroz \& O.F. Al-Sheikhly (2015). Lutrogale perspicillata. The IUCN Red List of Threatened Species 2015: e.T12427A21934884. Downloaded on 19 November 2021. https://doi.org/10.2305/IUCN.UK.2015-2.RLTS. T12427A21934884.en

Erlinge, S. (1972). The situation of the otter population in Sweden. Viltrevy 8: 379-397.

Green, J., R. Green \& D.J. Jefferies (1984). A radio-tracking survey of otter (Lutra lutra) on a Perthshire river system. Lutra 27: 85-145. https://www.iucnosgbull.org/Volume14/Volume14 Issue2.pdf

Hussain, S.A. (1993). Aspects of the ecology of Smooth-coated Indian Otter (Lutra perspicillata) in National Chambal Sanctuary. PhD Thesis, Aligarh Muslim University, xxiii+206 pp.

Hussain, S.A. (1996). Group size, group structure and breeding in Smooth-coated Otter (Lutra perspicillata) Geoffroy in National Chambal Sanctuary. Mammalia 60(2): 289-297.

Hussain, S.A. \& B.C. Choudhury (1997). Distribution and status of the Smooth-coated Otter (Lutra perspicillata) in National Chambal Sanctuary, India. Biological Conservation 80: 199-206.

Jayaram, K.C. (2000). Kaveri Riverine System: An Environmental Study, Madras Science Foundation, Chennai.

Jayaram, K.C. (1994). The freshwater fishes of India, Pakistan, 
Bangladesh, Burma and Sri lank - A Handbook. Zoological Survey India, Calcutta, xxii+475 pp.

Jefferies, D.J. (1966). The value of otter (Lutra lutra) surveying using spraints: an analysis of its success and problems in Britain. Journal of the Otter Trust 1(9): 25-32.

Jenkins, D. \& G.O. Burrows (1980). Ecology of otters in northern Scotland. III. The use of faeces as indicators of otter (Lutra lutra) density and distribution. Journal of Animal Ecology 49: 755-774. https://doi.org/10.2307/4225

Jenkins, D., J.G.K. Walker \& D. McGowan (1979). Analysis of the otter (Lutra lutra) faeces from Deeside, N.E. Scotland. Journal of Zoology, London 187: 235-144. https://doi.org/10.1111/j.1469-7998.1979. tb03946.x

Knudsen, G.J. \& J.B. Hale (1968). Food habits of otters in Great Lakes Region. Journal of Wildlife Management 32(10): 89-93. https://doi. org/10.2307/3798240

Kruuk, H. \& J.W.H. Conroy (1987). Surveying the otter (Lutra lutra) populations: a discussion of problems with spraints. Biological. Conservation 41(3): 179-183. https://doi.org/10.1016/00063207(87)90101-7

Kruuk, H. 1992. Scent marking by otters (Lutra lutra): Signaling the use of resources. Behavioural Ecology 3: 33-140.

Mason, C.F. \& S.M. Macdonald (1986). Otters - ecology and conservation. Cambridge University Press, $248 \mathrm{pp}$.

Mason, C.F. \& S.M. Macdonald (1987). The use of spraints to survey populations of otters (Lutra lutra). Biological Conservation 41(3): 167-177.

Meena, V. (2002). Otter poaching in Palni Hills. Zoos Print Journal. 17: 696-698.

Melquist W.E. \& A.E. Dronkert (1987). River otter North Bay, Ontario, Canada, pp. 625-641. In: Novak, M.J., A. Baker \& M.E. Obbard (eds.). Wild Furbearer Management and Conservation in North America.

Melquist, W.E. \& M.G. Hornocker (1983). Ecology of river otters in west central Idaho. Wildlife Monograph 83: 1-60.

Menon, V. (2003). A Field Guide to Indian Mammals. Penguin India and Dorling Kindersley, India, 164 pages.

Nagulu, V., C. Srinivasulu \& R. V. Vasudeva (1999a). Status of otter in southern Indian states: an updated report 1999. In: Envis Bulletin: Wildlife and Protected Areas 2(2): 71-73.

Nagulu, V., R.V. Vasudeva \& C. Srinivasulu (1999b). Curative property of otter blood - a belief. IUCN Otter Specialist. Group Bulletin 16(1): 44.

Nolet, B.A., D.E.H. Wansink \& H. Kruuk (1993). Diving of otters (Lutra lutra) in a marine habitat: use of depths by a single-prey loader. Journal of Animal Ecology 62: 22-32. https://doi.org/10.2307/5479
Norris, D. (1974). A study of the otter (L. lutra) on the R. Fergus from July to September 1974. Unpublished Wildlife Service Report.

Ottino, P. \& P. Giller (2004). Distribution, density, diet and habitat use of the otter in relation to land use in the Argali valley, Southern Ireland. Biology and Environment: Proceedings of the Royal Irish Academy 104(1): 1-17

Pardini, R. (1998). Feeding ecology of the Neotropical River Otter (Lontra longicaudis) in an Atlantic Forest Stream, south-eastern Brazil. Journal of Zoology (London.) 245: 385-391. https://doi. org/10.1111/j.1469-7998.1998.tb00113.x

Paterson, A.W. \& A.K. Whitfield (2000). Do shallow-water habitats function as refugia for juvenile fishes? Estuarine and Coastal Shelf Science 74: 263-273. https://doi.org/10.1006/ecss.2000.0640

Pocock, R.I. (1949). The Fauna of British India, including Ceylon and Burma, Vol. 2, Mammals. Taylor and Francis, London, xxxi+459 pp.

Prater, S.H. (1971). The Book of Indian Animals, $11^{\text {th }}$ impression, pp. 146-154. Bombay Natural History Society and Oxford University Press, Calcutta.

Raha, A. \& S.A. Hussain (2016). Factors affecting habitat selection by three sympatric otter species in the southern Western Ghats, India. Acta Ecologica Sinica 36: 45-49. https://doi.org/10.1016/j.chnaes. 2015.12.002

Reuther, C. (1999). From the Chairman's desk. IUCN Otter Spec. Group Bulletin 16: 3-6.

Rowe-Rowe, D.T. (1977). Food ecology of otters in Natal, South Africa. Oikos 28: 210-219.

Shariff, S.M. (1984). Some observations on otters at Kuala Gula, Perak and National Park, Pahang. Journal of Wildlife Parks 43: 2075-2488.

Shenoy, K. (2002). Habitat selection and diet composition of Smoothcoated Otters (Lutra perspicillata) in the Cauvery Wildlife Sanctuary, Karnataka, India. M.Sc. Dissertation. Pondicherry University, Pondicherry, India.

Shenoy, K. (2005). Otters in the River Cauvery, Karnataka. Occasional report no. 11. Wildlife Trust of India, $42 \mathrm{pp}$.

Shenoy, K., S. Varama \& K.V.D. Prasad (2006). Factors determining habitat choice of the smooth-coated otter, Lutra perspicillata in a south Indian river system. Current Science 91(5): 637-643.

Sivasothi, N. (1995). The status of otters (Carnivora: Mustelidae: Lutrinae) in Singapore and Malaysia, and the diet of smooth-coated otter (Lutrogale perspicillata) in Penang, West Malaysia. M.Sc. Thesis National University of Singapore, $86 \mathrm{pp}$.

Webb, J.B. (1976). Otter spraint analysis - Vol. 15. Mammal Society Publication, London, 52pp.

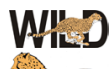



Dr. John Noyes, Natural History Museum, London, UK

Dr. Albert G. Orr, Griffith University, Nathan, Australia

Dr. Sameer Padhye, Katholieke Universiteit Leuven, Belgium

Dr. Nancy van der Poorten, Toronto, Canada

Dr. Kareen Schnabel, NIWA, Wellington, New Zealand

Dr. R.M. Sharma, (Retd.) Scientist, Zoological Survey of India, Pune, India

Dr. Manju Siliwal, WILD, Coimbatore, Tamil Nadu, India

Dr. G.P. Sinha, Botanical Survey of India, Allahabad, India

Dr. K.A. Subramanian, Zoological Survey of India, New Alipore, Kolkata, India

Dr. P.M. Sureshan, Zoological Survey of India, Kozhikode, Kerala, India

Dr. R. Varatharajan, Manipur University, Imphal, Manipur, India

Dr. Eduard Vives, Museu de Ciències Naturals de Barcelona, Terrassa, Spain

Dr. James Young, Hong Kong Lepidopterists' Society, Hong Kong

Dr. R. Sundararaj, Institute of Wood Science \& Technology, Bengaluru, India

Dr. M. Nithyanandan, Environmental Department, La Ala Al Kuwait Real Estate. Co. K.S.C.,

Kuwait

Dr. Himender Bharti, Punjabi University, Punjab, India

Mr. Purnendu Roy, London, UK

Dr. Saito Motoki, The Butterfly Society of Japan, Tokyo, Japan

Dr. Sanjay Sondhi, TITLI TRUST, Kalpavriksh, Dehradun, India

Dr. Nguyen Thi Phuong Lien, Vietnam Academy of Science and Technology, Hanoi, Vietnam

Dr. Nitin Kulkarni, Tropical Research Institute, Jabalpur, India

Dr. Robin Wen Jiang Ngiam, National Parks Board, Singapore

Dr. Lional Monod, Natural History Museum of Geneva, Genève, Switzerland.

Dr. Asheesh Shivam, Nehru Gram Bharti University, Allahabad, India

Dr. Rosana Moreira da Rocha, Universidade Federal do Paraná, Curitiba, Brasi

Dr. Kurt R. Arnold, North Dakota State University, Saxony, Germany

Dr. James M. Carpenter, American Museum of Natural History, New York, USA

Dr. David M. Claborn, Missouri State University, Springfield, USA

Dr. Kareen Schnabel, Marine Biologist, Wellington, New Zealand

Dr. Amazonas Chagas Júnior, Universidade Federal de Mato Grosso, Cuiabá, Brasil

Mr. Monsoon Jyoti Gogoi, Assam University, Silchar, Assam, India

Dr. Heo Chong Chin, Universiti Teknologi MARA (UiTM), Selangor, Malaysia

Dr. R.J. Shiel, University of Adelaide, SA 5005, Australia

Dr. Siddharth Kulkarni, The George Washington University, Washington, USA

Dr. Priyadarsanan Dharma Rajan, ATREE, Bengaluru, India

Dr. Phil Alderslade, CSIRO Marine And Atmospheric Research, Hobart, Australia

Dr. John E.N. Veron, Coral Reef Research, Townsville, Australia

Dr. Daniel Whitmore, State Museum of Natural History Stuttgart, Rosenstein, Germany.

Dr. Yu-Feng Hsu, National Taiwan Normal University, Taipei City, Taiwan

Dr. Keith V. Wolfe, Antioch, California, USA

Dr. Siddharth Kulkarni, The Hormiga Lab, The George Washington University, Washington,

D.C., USA

Dr. Tomas Ditrich, Faculty of Education, University of South Bohemia in Ceske

Budejovice, Czech Republic

Dr. Mihaly Foldvari, Natural History Museum, University of Oslo, Norway

Dr. V.P. Uniyal, Wildlife Institute of India, Dehradun, Uttarakhand 248001, India

Dr. John T.D. Caleb, Zoological Survey of India, Kolkata, West Bengal, India

Dr. Priyadarsanan Dharma Rajan, Ashoka Trust for Research in Ecology and the Environment

(ATREE), Royal Enclave, Bangalore, Karnataka, India

\section{Fishes}

Dr. Neelesh Dahanukar, IISER, Pune, Maharashtra, India

Dr. Topiltzin Contreras MacBeath, Universidad Autónoma del estado de Morelos, México

Dr. Heok Hee Ng, National University of Singapore, Science Drive, Singapore

Dr. Rajeev Raghavan, St. Albert's College, Kochi, Kerala, India

Dr. Robert D. Sluka, Chiltern Gateway Project, A Rocha UK, Southall, Middlesex, UK

Dr. E. Vivekanandan, Central Marine Fisheries Research Institute, Chennai, India

Dr. Davor Zanella, University of Zagreb, Zagreb, Croatia

Dr. A. Biju Kumar, University of Kerala, Thiruvananthapuram, Kerala, India

Dr. Akhilesh K.V., ICAR-Central Marine Fisheries Research Institute, Mumbai Research

Centre, Mumbai, Maharashtra, India

Dr. J.A. Johnson, Wildlife Institute of India, Dehradun, Uttarakhand, India

Amphibians

Dr. Sushil K. Dutta, Indian Institute of Science, Bengaluru, Karnataka, India

Dr. Annemarie Ohler, Muséum national d'Histoire naturelle, Paris, France

\section{Reptiles}

Dr. Gernot Vogel, Heidelberg, Germany

Dr. Raju Vyas, Vadodara, Gujarat, India

Dr. Pritpal S. Soorae, Environment Agency, Abu Dubai, UAE.

Prof. Dr. Wayne J. Fuller, Near East University, Mersin, Turkey

Prof. Chandrashekher U. Rivonker, Goa University, Taleigao Plateau, Goa. India

Dr. S.R. Ganesh, Chennai Snake Park, Chennai, Tamil Nadu, India

Dr. Himansu Sekhar Das, Terrestrial \& Marine Biodiversity, Abu Dhabi, UAE
Birds

Dr. Hem Sagar Baral, Charles Sturt University, NSW Australia

Dr. Chris Bowden, Royal Society for the Protection of Birds, Sandy, UK

Dr. Priya Davidar, Pondicherry University, Kalapet, Puducherry, India

Dr. J.W. Duckworth, IUCN SSC, Bath, UK

Dr. Rajah Jayapal, SACON, Coimbatore, Tamil Nadu, India

Dr. Rajiv S. Kalsi, M.L.N. College, Yamuna Nagar, Haryana, India

Dr. V. Santharam, Rishi Valley Education Centre, Chittoor Dt., Andhra Pradesh, India

Dr. S. Balachandran, Bombay Natural History Society, Mumbai, India

Mr. J. Praveen, Bengaluru, India

Dr. C. Srinivasulu, Osmania University, Hyderabad, India

Dr. K.S. Gopi Sundar, International Crane Foundation, Baraboo, USA

Dr. Gombobaatar Sundev, Professor of Ornithology, Ulaanbaatar, Mongolia

Prof. Reuven Yosef, International Birding \& Research Centre, Eilat, Israel

Dr. Taej Mundkur, Wetlands International, Wageningen, The Netherlands

Dr. Carol Inskipp, Bishop Auckland Co., Durham, UK

Dr. Tim Inskipp, Bishop Auckland Co, Durham, UK

Dr. V. Gokula, National College, Tiruchirappalli, Tamil Nadu, India

Dr. Arkady Lelej, Russian Academy of Sciences, Vladivostok, Russia

Dr. Simon Dowell, Science Director, Chester Zoo, UK

Dr. Mário Gabriel Santiago dos Santos, Universidade de Trás-os-Montes e Alto Douro,

Quinta de Prados, Vila Real, Portugal

Dr. Grant Connette, Smithsonian Institution, Royal, VA, USA

Dr. M. Zafar-ul Islam, Prince Saud Al Faisal Wildlife Research Center, Taif, Saudi Arabia

Mammals

Dr. Giovanni Amori, CNR - Institute of Ecosystem Studies, Rome, Italy

Dr. Anwaruddin Chowdhury, Guwahati, India

Dr. David Mallon, Zoological Society of London, UK

Dr. Shomita Mukherjee, SACON, Coimbatore, Tamil Nadu, India

Dr. Angie Appel, Wild Cat Network, Germany

Dr. P.O. Nameer, Kerala Agricultural University, Thrissur, Kerala, India

Dr. Ian Redmond, UNEP Convention on Migratory Species, Lansdown, UK

Dr. Heidi S. Riddle, Riddle's Elephant and Wildlife Sanctuary, Arkansas, USA

Dr. Karin Schwartz, George Mason University, Fairfax, Virginia.

Dr. Lala A.K. Singh, Bhubaneswar, Orissa, India

Dr. Mewa Singh, Mysore University, Mysore, India

Dr. Paul Racey, University of Exeter, Devon, UK

Dr. Honnavalli N. Kumara, SACON, Anaikatty P.O., Coimbatore, Tamil Nadu, India

Dr. Nishith Dharaiya, HNG University, Patan, Gujarat, India

Dr. Spartaco Gippoliti, Socio Onorario Società Italiana per la Storia della Fauna "Giuseppe

Altobello", Rome, Italy

Dr. Justus Joshua, Green Future Foundation, Tiruchirapalli, Tamil Nadu, India

Dr. H. Raghuram, The American College, Madurai, Tamil Nadu, India

Dr. Paul Bates, Harison Institute, Kent, UK

Dr. Jim Sanderson, Small Wild Cat Conservation Foundation, Hartford, USA

Dr. Dan Challender, University of Kent, Canterbury, UK

Dr. David Mallon, Manchester Metropolitan University, Derbyshire, UK

Dr. Brian L. Cypher, California State University-Stanislaus, Bakersfield, CA

Dr. S.S. Talmale, Zoological Survey of India, Pune, Maharashtra, India

Prof. Karan Bahadur Shah, Budhanilakantha Municipality, Kathmandu, Nepal

Dr. Susan Cheyne, Borneo Nature Foundation International, Palangkaraja, Indonesia

Dr. Hemanta Kafley, Wildlife Sciences, Tarleton State University, Texas, USA

\section{Other Disciplines}

Dr. Aniruddha Belsare, Columbia MO 65203, USA (Veterinary)

Dr. Mandar S. Paingankar, University of Pune, Pune, Maharashtra, India (Molecular)

Dr. Jack Tordoff, Critical Ecosystem Partnership Fund, Arlington, USA (Communities)

Dr. Ulrike Streicher, University of Oregon, Eugene, USA (Veterinary)

Dr. Hari Balasubramanian, EcoAdvisors, Nova Scotia, Canada (Communities)

Dr. Rayanna Hellem Santos Bezerra, Universidade Federal de Sergipe, São Cristóvão, Brazil

Dr. Jamie R. Wood, Landcare Research, Canterbury, New Zealand

Dr. Wendy Collinson-Jonker, Endangered Wildlife Trust, Gauteng, South Africa

Dr. Rajeshkumar G. Jani, Anand Agricultural University, Anand, Gujarat, India

Dr. O.N. Tiwari, Senior Scientist, ICAR-Indian Agricultural Research Institute (IARI), New

Delhi, India

Dr. L.D. Singla, Guru Angad Dev Veterinary and Animal Sciences University, Ludhiana, India

Dr. Rupika S. Rajakaruna, University of Peradeniya, Peradeniya, Sri Lanka

Dr. Bahar Baviskar, Wild-CER, Nagpur, Maharashtra 440013, India

Reviewers 2018-2020

Due to pausity of space, the list of reviewers for $2018-2020$ is available online.

The opinions expressed by the authors do not reflect the views of the Journal of Threatened Taxa, Wildlife Information Liaison Development Society, Zoo Outreach Organization, or any of the partners. The journal, the publisher, the host, and the partners are not responsible for the accuracy of the political boundaries shown in the maps by the authors.

Journal of Threatened Taxa is indexed/abstracted in Bibliography of Systematic Mycology, Biological Abstracts, BIOSIS Previews, CAB Abstracts, EBSCO, Google Scholar, Index Copernicus, Index Fungorum, JournalSeek, National Academy of Agricultural Sciences, NewJour, OCLC WorldCat, SCOPUS, Stanford University Libraries, Virtual Library of Biology, Zoological Records.

NAAS rating (India) 5.64
Print copies of the Journal are available at cost. Write to:

The Managing Editor, JoTT,

c/o Wildlife Information Liaison Development Society,

No. 12, Thiruvannamalai Nagar, Saravanampatti - Kalapatti Road,

Saravanampatti, Coimbatore, Tamil Nadu 641035, India

ravi@threatenedtaxa.org 


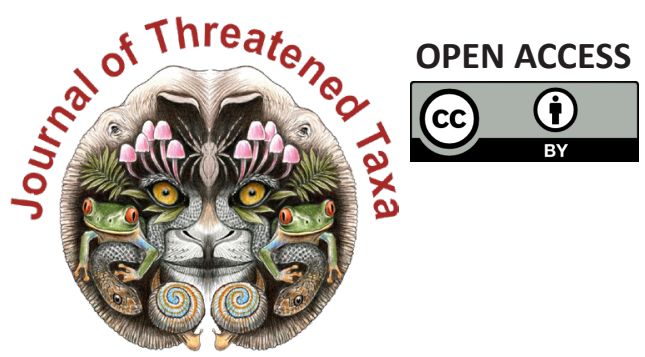

www.threatenedtaxa.org

The Journal of Threatened Taxa (JoTT) is dedicated to building evidence for conservation globally by publishing peer-reviewed articles online every month at a reasonably rapid rate at www.threatenedtaxa.org. All articles published in JoTT are registered under Creative Commons Attribution 4.0 International License unless otherwise mentioned. JoTT allows allows unrestricted use, reproduction, and distribution of articles in any medium by providing adequate credit to the author(s) and the source of publication.

\section{ISSN $0974-7907$ (Online) | ISSN $0974-7893$ (Print)}

\section{January 2022 | Vol. 14 | No. 1 | Pages: 20311-20538 \\ Date of Publication: 26 January 2022 (Online \& Print) DOI: 10.11609/jott.2022.14.1.20311-20538}

Articles

Estimating the completeness of orchid checklists and atlases: a case study from southern Italy

- Antonio Croce, Pp. 20311-20322

A floristic survey across three coniferous forests of Kashmir Himalaya, India - a checklist

- Ashaq Ahmad Dar, Akhtar Hussain Malik \& Narayanaswamy Parthasarathy, Pp. 20323-20345

Associations of butterflies across different forest types in Uttarakhand, western Himalaya, India: implications for conservation planning

- Arun Pratap Singh, Pp. 20346-20370

Comparison of bird diversity in protected and non-protected wetlands of western lowland of Nepal

- Jagan Nath Adhikari, Janak Raj Khatiwada, Dipendra Adhikari, Suman Sapkota, Bishnu Prasad Bhattarai, Deepak Rijal \& Lila Nath Sharma, Pp. 20371-20386

Local hunting practices and perceptions regarding the distribution and ecological role of the Large Flying Fox (Chiroptera: Pteropodidae: Pteropus vampyrus) in western Sarawak, Malaysian Borneo

- Jayasilan Mohd-Azlan, Joon Yee Yong, Nabila Norshuhadah Mohd Hazzrol, Philovenny Pengiran, Arianti Atong \& Sheema Abdul Aziz, Pp. 20387-20399

\section{Communications}

Macrolichens of Mathikettan Shola National Park, Western Ghats: a preliminary investigation with some new records

- Aswathi Anilkumar, Stephen Sequeira, Arun Christy \& S.M. Arsha, Pp. 20400-20405

New distribution record of globally threatened Ocean Turf Grass Halophila beccarii Ascherson, 1871 from the North Andaman Islands highlights the importance of seagrass exploratory surveys

- Swapnali Gole, Prasad Gaidhani, Srabani Bose, Anant Pande, Jeyaraj Antony Johnson \& Kuppusamy Sivakumar, Pp. 20406-20412

An inventory of new orchid (Orchidaceae) records from Kozhikode, Kerala, India - M. Sulaiman, C. Murugan \& M.U. Sharief, Pp. 20413-20425

Abundance and spatial distribution analyses of Stemonoporus moonii Thwaites (Dipterocarpaceae) - a critically endangered species endemic to Sri Lanka - K.A.M.R.P. Atapattu, H.D.D.C.K. Perera, H.S. Kathriarachchi \& A.R. Gunawardena, Pp. 20426-20432

Plant diversity of Point Calimere Wildlife Sanctuary and fodder species grazed by the Blackbuck Antilope cervicapra L.

- Ashutosh Kumar Upadhyay, A. Andrew Emmanuel, Ansa Sarah Varghese \&

D. Narasimhan, Pp. 20433-20443

Raptors observed (1983-2016) in National Chambal Gharial Sanctuary: semi-arid biogeographic region suggestions for parametric studies on ecological continuity in Khathiar-Gir Ecoregion, India

- L.A.K. Singh, R.K. Sharma \& Udayan Rao Pawar, Pp. 20444-20460

Nesting success of Sharpe's Longclaw (Macronyx sharpei Jackson, 1904) around the grasslands of lake Ol'bolossat Nyandarua, Kenya

- Hamisi Ann Risper, Charles M. Warui \& Peter Njoroge, Pp. 20461-20468

Population, distribution and diet composition of Smooth-coated Otter Lutrogale perspicillata Geoffroy, 1826 in Hosur and Dharmapuri Forest Divisions, India - Nagarajan Baskaran, Raman Sivaraj Sundarraj \& Raveendranathanpillai Sanil, Pp. 20469-20477

Utilization of home garden crops by primates and current status of human-primate interface at Galigamuwa Divisional Secretariat Division in Kegalle District, Sri Lanka

- Charmalie Anuradhie Dona Nahallage, Dahanakge Ayesha Madushani Dasanayake, Dilan Thisaru Hewamanna \& Dissanayakalage Tharaka Harshani Ananda, Pp. 2047820487
Revival of Eastern Swamp Deer Rucervus duvaucelii ranjitsinhi (Groves, 1982) in Manas National Park of Assam, India

- Nazrul Islam, Aftab Ahmed, Rathin Barman, Sanatan Deka, Bhaskar Choudhury, Prasanta Kumar Saikia \& Jyotishman Deka, Pp. 20488-20493

Trypanosoma evansi infection in a captive Indian Wolf Canis lupus pallipes - molecular diagnosis and therapy

- Manojita Dash, Sarat Kumar Sahu, Santosh Kumar Gupta, Niranjana Sahoo \& Debarat Mohapatra, Pp. 20494-20499

View Point

COVID-19 and civil unrest undoing steady gains in karst conservation and herpetological research in Myanmar, and an impediment to progress - Evan S.H. Quah, Lee L. Grismer, Perry L. Wood, Jr., Aung Lin \& Myint Kyaw Thura, Pp. 20500-20502

\section{Short Communications}

Morphological characterization and mt DNA barcode of a tiger moth species, Asota ficus (Fabricius, 1775) (Lepidoptera: Noctuoidea: Erebidae: Aganainae) from India - Aparna Sureshchandra Kalawate, K.P. Dinesh \& A. Shabnam, Pp. 20503-20510

Distribution of Smooth-coated Otters Lutrogale perspicillata (Mammalia: Carnivora: Mustelidae): in Ratnagiri, Maharashtra, India

- Swanand Patil \& Kranti Yardi, Pp. 20511-20516

Wildlife at the crossroads: wild animal road kills due to vehicular collision on a mountainous highway in northwestern Himalayan region

- Muzaffar A. Kichloo, Asha Sohil \& Neeraj Sharma, Pp. 20517-20522

Notes

Robiquetia gracilis (Lindl.) Garay-a new record to the flora of Anamalai Hills, Tami Nadu, India

- B. Subbaiyan, V. Ganesan, P.R. Nimal Kumar \& S. Thangaraj Panneerselvam, Pp. 20523-20525

Ipomoea laxiflora H.J. Chowdhery \& Debta (Convolvulaceae): new records for the Western Ghats and semiarid regions

- Sachin M. Patil, Ajit M. Vasava, Vinay M. Raole \& Kishore S. Rajput, Pp. 20526-20529

Counting the cost: high demand puts Bunium persicum (Boiss.) B.Fedtsch. in jeopardy

- Monika Sharma, Manisha Mathela, Rupali Sharma, Himanshu Bargali, Gurinderjit S Goraya \& Amit Kumar, Pp. 20530-20533

First record of Parasitic Jaeger Stercorarius parasiticus (Aves: Charadriiformes: Stercorariidae) from inland freshwater Inle Lake, Myanmar

- Sai Sein Lin Oo, Myint Kyaw, L.C.K. Yun, Min Zaw Tun, Yar Zar Lay Naung, Soe Naing Aye \& Swen C. Renner, Pp. 20534-20536

\section{Book Review}

Capparis of India

- V. Sampath Kumar, Pp. 20537-20538
Publisher \& Host
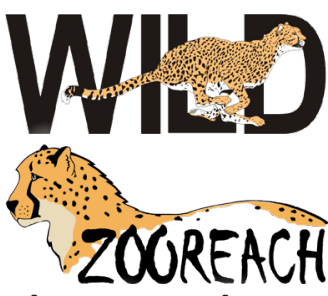

Threatened Taxa 